\title{
Brazilian Society of Dermatology against leprosy*
}

Joel Carlos Lastória ${ }^{1}$

Marilda Aparecida Milanez Morgado de Abreu²

DOI: http:/ / dx.doi.org/10.1590/abd1806-4841.20164648

Abstract: The Brazilian Society of Dermatology promoted a national campaign against leprosy in 2012, involving their State Regional, Accredited Services of Dermatology and Referral Services in Leprosy. Consisted of clarification to the population about the disease and a day of medical voluntary service. Ninety services (57 Accredited Services and 33 Reference Services) participated, distributed in 23 states. The campaign examined 3,223 people and 421 new cases were diagnosed, 54,4\% female, 74,3\% between 19 and 64 years and 8,3\% in children under 15 years. Of the 217 classified cases, 58,5\% was paucibacillary and 41,5\% was multibacillary. The results were posted on the Brazilian Society of Dermatology website.

Keywords: Communicable disease prevention; Communicable disease control; Diagnosis; Epidemiology; Leprosy

Leprosy remains a public health problem in Brazil, with a prevalence rate of 1.42 cases per 10,000 inhabitants and 31,044 new cases diagnosed in 2013. Our country ranks second in the absolute number of cases, only behind India. Integrated services and partnerships sustain actions for disease control. ${ }^{1,2}$

The detection and early treatment of cases is critical to break the chain of transmission and to prevent physical disabilities. The awareness campaigns and massive test of the population is one of the strategies used. ${ }^{2,3}$

In order to provide the population support to early diagnosis of leprosy, the Brazilian Society of Dermatology (SBD) held a national campaign in 2012.

The action consisted of SBD interrelation with its regional and state groups and of these with the respective accredited dermatology services and referral services for leprosy. It received the support of the Brazilian Society of Leprosy, General Coordination for Leprosy, Diseases in Elimination (Health Surveillance
Secretariat, Ministry of Health), Movement for Reintegration of People Affected by Leprosy and Paulista Foundation against Leprosy. The coordination of the campaign was conducted in three scopes: national, state and local. In April 2012, educational materials were distributed, including brochures, posters, banners and bands, and interviews and lectures were performed in the media to publicize the campaign as well as education to the population (Figures 1 and 2). The action strategies were: to promote knowledge about the signs and symptoms of leprosy, raise awareness about the importance of early diagnosis and treatment and encourage those with suspicious lesions to seek medical attention. The official launch of the campaign was in Rio de Janeiro on May 2nd, 2012, culminating in a campaign for medical care on May 5th, from 9 a.m. to 3 p.m., in all participating services.

In total, 90 services participated in the campaign, distributed in 23 states in the nation: 57 accredited dermatology services and 33 referral services for leprosy.

Received on 19.04.2015

Approved by the Advisory Board and accepted for publication on 13.07.2015

Study performed at Universidade Estadual Paulista “Júlio de Mesquita Filho" (Unesp) and at Hospital Regional de Presidente Prudente, of the Universidade do Oeste Paulista (HRPP-Unoeste), Brazil.

Financial Support: None.

Conflict of Interest: None.

Universidade Estadual Paulista "Júlio de Mesquita Filho" (Unesp) - Botucatu (SP), Brazil.

Universidade do Oeste Paulista (Unoeste) - Presidente Prudente (SP), Brazil.

C2016 by Anais Brasileiros de Dermatologia 


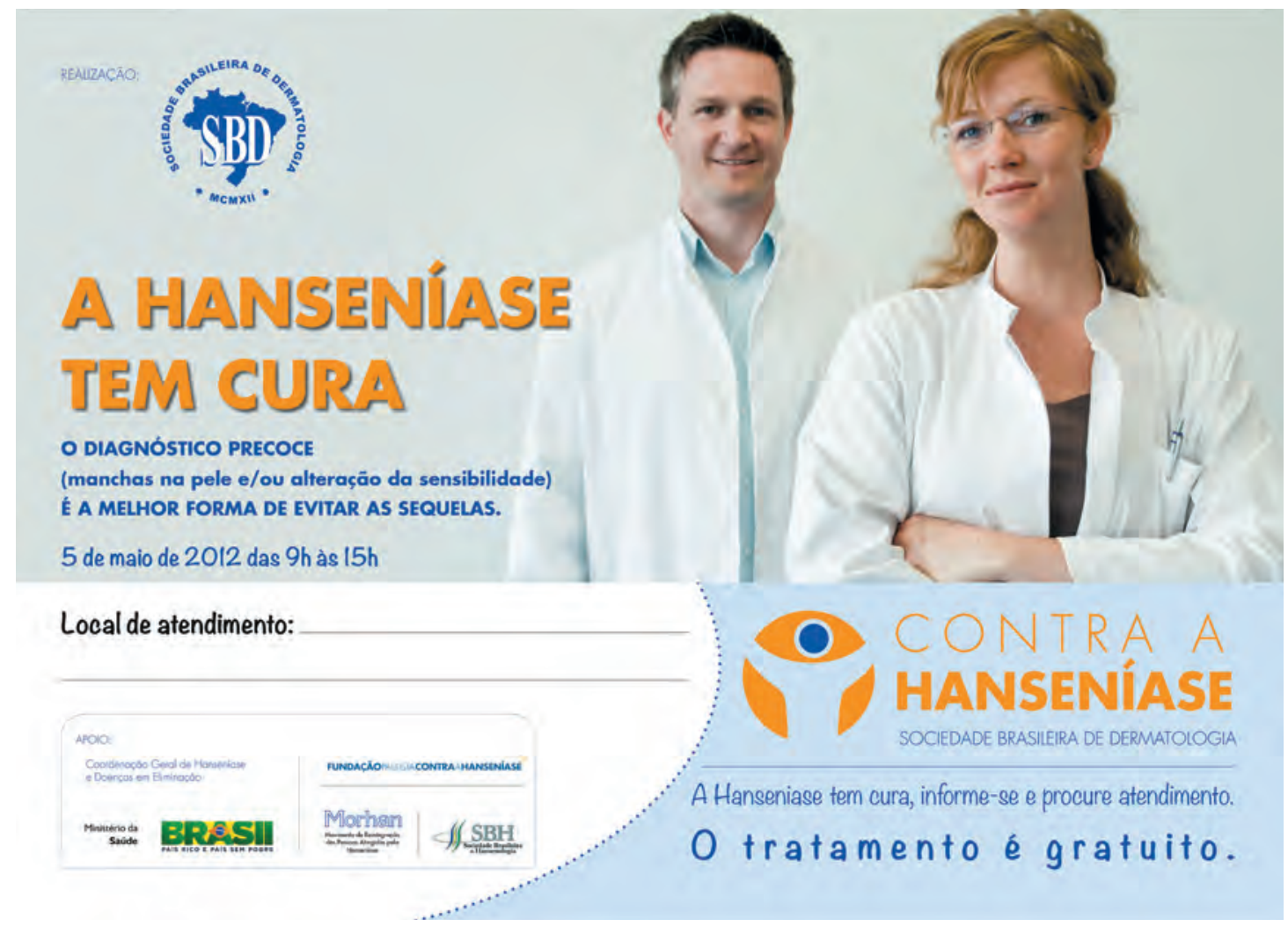

Figure 1 : Campaign publicity material: poster, banner and band

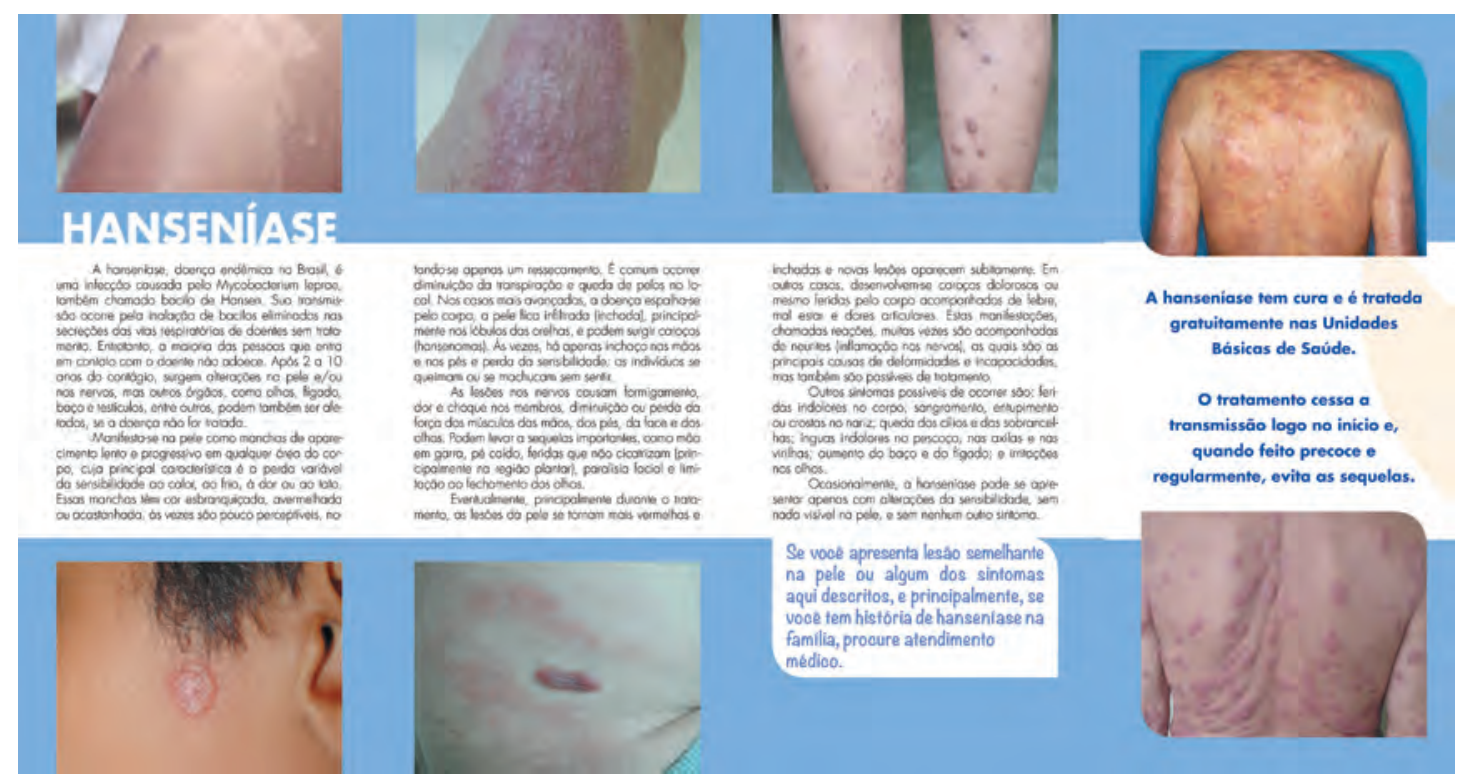

FIGURE 2 : Campaign educational material: brochure

3,223 people were examined: 1,201 (37.3\%) men and $2,022(62.7 \%)$ women. Of this total, $403(12.5 \%)$ presented leprosy skin lesion and $18(0.5 \%)$, only neurological changes, totaling 421 (13\%) diagnosed cases. Most affected individuals were women $(54.4 \%)$ and brown $(50.83 \%)$. Regarding age, $74.3 \%$ were aged 19 64 years and $8.3 \%$ were younger than 15 years. The states that diagnosed the largest number of cases were
São Paulo (24.2\%), Rio de Janeiro (15.2\%), Rondônia $(14 \%)$ and Federal District (12.1\%). Of the 217 classified cases, $58.5 \%$ were paucibacillary and $41.5 \%$ were multibacillary, and $50(23 \%)$ had indeterminate form. Spreadsheets were analyzed and the results were published in the SBD website.

The largest number of cases diagnosed in São Paulo and Rio de Janeiro may be justified by higher 
research, due to the higher number of participating services, 17 and 19, respectively. The number of existing dermatology accredited services in most other states is much lower. Except for Rondônia, where the prevalence of leprosy is still high, the large number of new cases diagnosed in states where leprosy is already eliminated as a public health problem was surprising. Therefore, the campaign not only put the leprosy in evidence for the population and health professionals, but also caused great impact on statistical indicators in some states. Without the SBD campaign, many of these cases would be diagnosed later and, surely, they would be within the hidden prevalence for a longer time. This shows that campaigns for the active search for new cases are a necessary strategy for countries where leprosy is endemic.

We highlight the importance of the campaign in assisting the elimination of leprosy as a public health problem in Brazil, the adherence of nationwide services, the participation of dermatologists in volunteering, the partnerships, and the education about the disease to the population and the diagnosis of 421 new cases, with a high percentage of indeterminate form, which means early diagnosis.

This report shows the results of the campaign "Brazilian Society of Dermatology in the fight against leprosy," conducted by the Brazilian Society of Der- matology during the 2011-2012 management. It was written by the coordinators of the campaign, Dr. Joel Carlos Lastória and Dr. Marilda Aparecida Milanez Morgado de Abreu.

SBD Board 2011-2012: President - Bogdana Victória Kadunc; Vice President - Sarita Maria F. Martins; General Secretary - Leandra D'Orsi Metsavaht; First Secretary - Eliandre Costa Palermo; Second Secretary - Luciana Rabello Silveira de Oliveira; Treasurer - Carlos Baptista Barcaui.

Department of Leprosy: Coordinator - Joel Carlos Lastória; Sub-coordinator - Dilhermando Augusto Calil; Secretary - Maria Angela Bianconcini Trinity.

\section{ACKNOWLEDGEMENTS}

SBD thanks the dedication of its regional and state groups, accredited dermatology services, referral services for leprosy and teams of volunteers. We also thank the support of the Brazilian Society of Leprosy, General Coordination for Leprosy, Diseases in Elimination (Health Surveillance Secretariat, Ministry of Health), Movement for Reintegration of People Affected by Leprosy, and Paulista Foundation against Leprosy.

\section{REFERENCES}

1. Portalsaude.saude.gov.br [Internet]. Sinan/SVS-MS. Situação Epidemiológica Dados. [acesso 11 mar 2015]. Disponível em: http://portalsaude.saude.gov.br/ images/pdf/2014/dezembro/01/Dados-2013.pdf.

2. Global leprosy update, 2013; reducing disease burden. Wkly Epidemiol Rec 2014;89:389-400.

3. Lastória JC, Abreu MA.. Hanseníase: revisão dos aspectos epidemiológicos, etiopatogênicos e clínicos - Parte I. An Bras Dermatol. 2014;89:205-18.

\author{
MAILING ADDRESS: \\ Marilda Aparecida Milanez Morgado de Abreu \\ Hospital Regional de Presidente Prudente/Unoeste \\ Rua José Bongiovani, 1.297 \\ Vila Liberdade \\ 19050-680 - Presidente Prudente - SP \\ Brazil \\ Email:marildaderma@bol.com.br
}

How to cite this article: Lastória JC, Morgado de Abreu MAM. Dermatology Brazilian Society against leprosy. An Bras Dermatol. 2016:91(3):293-5. 